J. Great Lakes Res. 30 (Supplement 1):196-213

Internat. Assoc. Great Lakes Res., 2004

\title{
Annual and Offshore Changes in Bacterioplankton Communities in the Western Arm of Lake Superior during 1989 and 1990
}

\author{
Randall E. Hicks*, Peter Aas ${ }^{\dagger}$, and Christine Jankovich \\ Department of Biology \\ University of Minnesota-Duluth \\ Duluth, Minnesota 55812
}

\begin{abstract}
A shallow site in the western arm of Lake Superior near Duluth, Minnesota was sampled bimonthly from May to October during 1989 and 1990 to identify seasonal and annual changes in bacterioplankton communities. The greatest change in bacterioplankton abundance was between 1989 $\left(1.48 \times 10^{9} / \mathrm{L} \pm 0.06 \mathrm{SE}\right)$ and $1990\left(1.14 \times 10^{9} / \mathrm{L} \pm 0.06 \mathrm{SE}\right)$. The majority of bacterial cells $(65 \%)$ were cocci. Individual cells were larger during 1989 (0.067 $\left.\mathrm{mm}^{3} \pm 0.007 \mathrm{SE}\right)$ than $1990\left(0.025 \mu \mathrm{m}^{3} \pm 0.002\right.$ $S E)$. Although the rate of thymidine incorporation varied from 0.2 to $47.0 \mathrm{pmol} / \mathrm{L} / \mathrm{h}$ over both years $($ mean $=12.1 \mathrm{pmol} / \mathrm{L} / \mathrm{h} \pm 1.3 \mathrm{SE})$, no consistent temporal or spatial changes were detected. Bacteria were more abundant $(\sim 2 \times)$ and productive $(\sim 10 \times)$ at the mouth of the Lester River than offshore of this site. During July and August, a benthic nepheloid layer (BNL) formed at shallow offshore sites but bacterioplankton abundance and production in this BNL were usually similar to values measured in the hypolimnion. Three additional sites from the Duluth basin northeast to the Chefswet basin were sampled during late summer (Aug-Sept) 1990 to identify spatial differences in bacterioplankton communities. Although the number of bacteria was often greater at shallower sites compared to deeper sites further offshore, a strong gradient was not found and bacterial production was similar at all sites. These results may be due in part to the lake basin morphology in this region of Lake Superior, as well as the time when these additional offshore sites were investigated.
\end{abstract}

INDEX WORDS: Bacterioplankton, cell morphology, biovolume, thymidine incorporation, production, benthic nepheloid layer, Lake Superior, offshore gradients.

\section{INTRODUCTION}

Bacterioplankton production changes in freshwater and marine systems because of the close coupling of bacteria with phytoplankton production and protistan grazing (Scavia and Laird 1987, Cole et al. 1988, Sherr et al. 1992, Hwang and Heath 1997). Bacterial biomass represents one of the most readily utilizable and protein rich food sources for aquatic microconsumers (Azam et al. 1983, Murray and Hodson 1985, Hwang and Heath 1997). Although its value as a carbon source for heterotrophic nanoplankton $(<64 \mu \mathrm{m})$ has been questioned (Ducklow et al. 1986, Pernie et al. 1990), more recent evidence indicates this view may be incorrect (Hwang

\footnotetext{
*Corresponding author. E-mail: rhicks@d.umn.edu

$\dagger$ Present Address: Abbott Northwestern Hospital, 2800 Chicago Ave., Minneapolis, MN 55407

$\$$ Present Address: DuPont Soy Polymers, 3RN, P. O. Box 88940, St. Louis, MO 63188
}

and Heath 1999). Heterotrophic bacteria are often the major decomposers of dissolved and particulate organic matter and important agents of nutrient regeneration besides being a potential food item in aquatic systems (Caron et al. 1985, Kirchman et al. 1991, Biddanda et al. 2001). In oligotrophic systems like Lake Superior, Cotner and Biddanda (2002) suggested that procaryotic heterotrophs are favored over phytoplankton and phagotrophic heterotrophs because a high proportion of dissolved nutrients are organic and a high proportion of available organic carbon is dissolved.

Even though bacterial abundance and production are related to phytoplankton abundance and primary production in most aquatic systems, riverine inputs and intermittent sediment resuspension caused by storms may confound these relationships (Robarts 1987, Wainright 1990, Cotner et al. 2000, Auer and Powell 2004). The effects of coupling bacterial communities with all these processes can result in tem- 
poral and spatial changes in bacterioplankton abundance and production (Moll and Brahce 1986, Pace 1988, Coveney and Wetzel 1992). Increased knowledge about temporal and spatial changes in bacterioplankton communities can help identify the frequency of events like phytoplankton blooms, terrestrial inputs, and sediment resuspension that can control bacterioplankton dynamics. In addition, though, such studies are necessary to understand long-term trends and recognize other factors responsible for change.

The abundances, and oftentimes the production, of autotrophic nanoplankton and picoplankton $(<1$ $\mu \mathrm{m})$, heterotrophic nanoflagellates, and ciliated protozoa have been measured in Lake Superior $(\mathrm{Mu}-$ nawar et al. 1978, Fahnenstiel et al. 1986, Munawar and Munawar 2001). While bacterioplankton have been studied in other Laurentian Great Lakes, information about their seasonal and spatial distributions and production in Lake Superior remains scarce. This paper reports the abundances, cell shapes and biovolumes, and production of bacterioplankton measured in the western arm of Lake Superior during 1989 and 1990. In addition to cell abundances, cell shapes can give insights about changes in bacterioplankton communities. Information about cell biovolume complements production measurements because size distributions can change as growth rates vary (Ammerman et al. 1984). These data were used to identify seasonal and annual changes in bacterial biomass and production, help define nominal values, and evaluate spatial differences in bacterioplankton communities in the western portion of Lake Superior, especially differences related to benthic nepheloid layers (BNLs) and onshore-offshore gradients.

\section{METHODS}

\section{Site Descriptions and Sample Collection}

Bacterioplankton abundance and activity were measured approximately bimonthly for two years at one site in the Duluth depositional basin from May until October. Site LR-3 (46 $\left.28.20^{\prime} \mathrm{N}, 91^{\circ} 58.18^{\prime} \mathrm{W}\right)$ is located $3.8 \mathrm{~km}$ southeast of the Lester River near Duluth, MN (Fig. 1). The lake is $35 \mathrm{~m}$ deep at this site. Water was collected from 1, 10, 20, 30, and 33 m during 1989 and 1990 using a polyvinylchloride VanDorn bottle. On several occasions, water samples were also taken at $5 \mathrm{~m}$. Site LR-3 was sampled on 29 May, 15 Jun, 13 Jul, 7 and 30 Aug, and 13 Oct in 1989. During 1990, it was sampled on 4 May, 12 Jun, 18 Jul, 14 Aug, 25 Sept, and 16 Oct. Water was

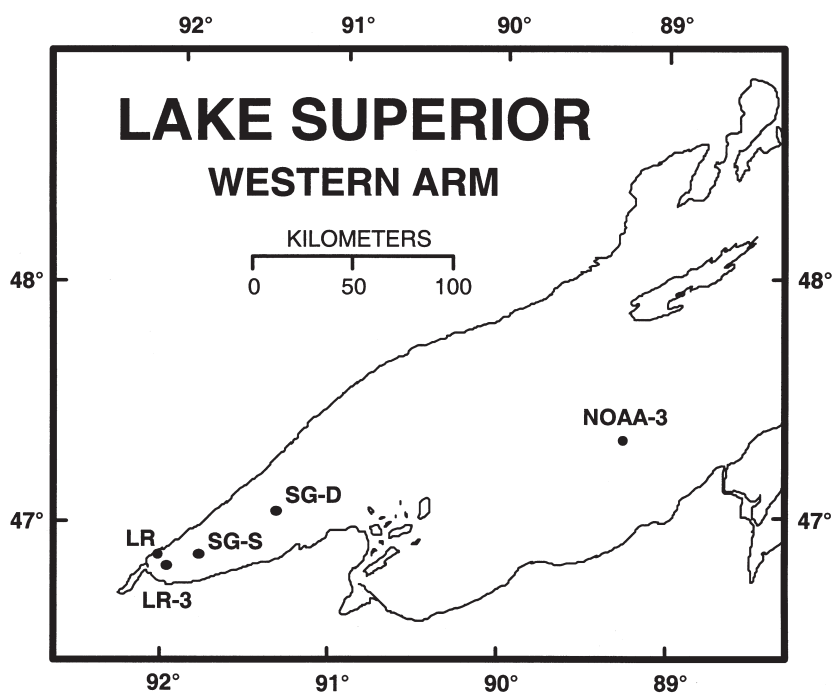

FIG 1. Map of the western arm of Lake Superior. Site LR-3 was sampled approximately bimonthly during 1989 and 1990. The mouth of the Lester River (LR) was sampled seven times on the same day or within a few days of other sites during 1989 and 1990. The other sites in the Duluth basin (SG-S, SG-D) and the Chefswet basin (NOAA-3) were only sampled during late August or early September 1990.

also collected at the mouth of the Lester River (site LR; $46^{\circ} 49.60^{\prime} \mathrm{N}, 91^{\circ} 59.99^{\prime} \mathrm{W}$ ) seven times during 1989 (17 Jun, 12 Jul, 8 Aug, 6 Sept) and 1990 (4 May, 15 Aug, $25 \mathrm{Sept}$ ) to compare chemical and bacterial measurements to offshore areas (Fig. 1). Surface water samples $(0.2 \mathrm{~m})$ were collected by immersing $20 \mathrm{~L}$ carboys below the water surface. All water samples from offshore sites were processed immediately aboard ship. River water samples were refrigerated, returned to the lab, and analyzed there (typically within 1 to 4 hours of collection).

On each date, subsamples of water were distributed for bacterioplankton measurements immediately after sampling (see details below). Water temperature was measured with a YSI (Model 58) temperature probe. Water for suspended solids, particulate organic carbon (POC), and dissolved organic carbon (DOC) measurements was collected at the same depths at offshore sites with a submersible pump attached to Tygon tubing (Hicks and Owen 1991). At least two subsamples $(2.5-4.0 \mathrm{~L})$ were filtered through preweighed and ashed glass fiber filters (Whatman GF/C). Filtered samples were dried at $60^{\circ} \mathrm{C}$ to constant weight and reweighed to measure 
suspended solids. POC concentrations were measured with a dichromate wet oxidation method (Parsons et al. 1984). Inorganic carbon was not measured; it does not interfere with the POC method. Dissolved organic carbon (DOC) concentrations of $\mathrm{GF} / \mathrm{C}$ filtrates were measured with a Dohrman carbon analyzer (Hicks and Owen 1991).

Additional water samples were collected from three other sites in the western arm of Lake Superior during later summer 1990 to investigate the spatial distribution of bacterioplankton abundance and activity (Fig. 1). The first and second sites were in the Duluth depositional basin. The shallower site $(71 \mathrm{~m}$ deep), SG-S $\left(46^{\circ} 51.00^{\prime} \mathrm{N}, 91^{\circ} 45.80^{\prime} \mathrm{W}\right)$, was $13 \mathrm{~km}$ northeast of site LR-3. The second site, SG-D $\left(47^{\circ} 01.82^{\prime} \mathrm{N}, 91^{\circ} 18.26^{\prime} \mathrm{W}\right)$, was located east of Two Harbors, Minnesota, $47 \mathrm{~km}$ from LR-3, and is 164 $\mathrm{m}$ deep. The third site, NOAA-3 $\left(47^{\circ} 19.88^{\prime} \mathrm{N}\right.$, $89^{\circ} 14.99^{\prime} \mathrm{W}$; $184 \mathrm{~m}$ deep), was in the Chefswet depositional basin near the Keweenaw Peninsula. Water at these three sites was collected aboard the R/V Seward Johnson and the Johnson-Sea-Link II (JSL-II) research submersible (Harbor Branch Oceanographic Institute, Inc., Fort Pierce, FL) from 27 Aug to 1 Sept 1990. Surface (5 m) and hypolimnetic $(40 \mathrm{~m})$ water was collected from the ship using a submersible pump (Hicks and Owen 1991). An additional sample was collected at each site from $1 \mathrm{~m}$ above the sediment-water interface through an autoclaved Nalgene tube (3-mm diameter) connected to the robotic arm of the JSL-II submersible (McKee $e t$ al. 1989, Hicks and Owen 1991). All samples were collected in acid-washed bottles that had been rinsed with $0.2 \mu \mathrm{m}$-filtered Milli-Q water. Subsamples for direct counts, suspended solids, POC, and DOC were taken immediately and the remaining sample was refrigerated $\left(6^{\circ} \mathrm{C}\right.$; typically less than $1 \mathrm{~h}$ ) until thymidine incorporation could be measured.

Three sites were used to investigate the relationships between cell production and thymidine incorporation. Water samples were collected at site LR (16 Jun 89), site LR-3 (16 Jun 89 and 25 Jul 90) and site NOAA-3 (27 Aug 90). Surface water samples $(0.2 \mathrm{~m})$ were collected at the Lester River sites by immersing $20 \mathrm{~L}$ carboys below the water surface. At NOAA-3, water samples were collected at $5 \mathrm{~m}$ and $183 \mathrm{~m}$ using a submersible pump and the JSL-II submersible, respectively. All water was refrigerated until the experiments relating bacterial cell production to the rate of thymidine incorporation were started (1-4 hours).

\section{Bacterioplankton Measurements}

\section{Bacterioplankton Abundance}

Three 10-mL subsamples from each sample were preserved immediately with formaldehyde $(0.2 \mu \mathrm{m}$ filtered, $2 \%$ final concentration), refrigerated, and counted within 2 weeks. The total number of bacterial cells was determined by epifluorescent direct counts (Zeiss microscope, total magnification 1,250 x) of DAPI-stained cells (Hobbie et al. 1977, Porter and Feig 1980).

\section{Cell Morphology and Biovolume}

Representative microscopic fields from each subsample were photographed to categorize cell shapes and measure cellular dimensions. The shapes and dimensions of bacterial cells were analyzed for 34 and 38 different dates and depths in 1989 and 1990, respectively. Typically, five depths were sampled on six different dates each year. Between 13 and 101 cells $($ mean $=42$ ) were examined at each depth. More than 1,280 individual cells were examined in 1989 and more than 1,795 cells in 1990. Cells were categorized into one of five cell shapes (coccus, rod, vibrio, filament, and spiral). The percentages of cells with different shapes were calculated for each date and depth and used to construct contoured scatter plots using negative exponential interpolation (Wilkinson 1989a, McLain 1974).

Bacterial cell dimensions were measured on projected photomicrographs with a graduated caliper and corrected for enlargement using a photomicrograph of a stage micrometer. Cocci volumes were calculated assuming a spherical shape while rod- and filament-shaped cell volumes were estimated using the equation for a cylinder. Volumes of vibrioshaped cells were calculated by the equation: volume $\left(\mu \mathrm{m}^{3}\right)=\pi^{2} \mathrm{Rr}^{2}-(2 / 3) \pi r^{3}$, where $\mathrm{R}$ is the vibrio width and $r$ is the cell radius (e.g., $0.5 \times$ cell width). Spiral volumes were calculated with the equation: volume $\left(\mu \mathrm{m}^{3}\right)=\left[\left(\pi \mathrm{d}^{2}\right) / 4\right] \times \operatorname{SQRT}\left[\pi^{2} \mathrm{D}^{2} \mathrm{H}^{2}\right]$, where $\mathrm{d}$ is the cell width, D is the spiral width, and $\mathrm{H}$ is the spiral length. Average cell volume for all bacterioplankton was estimated by averaging the biovolumes of individual cells in each sample.

\section{Thymidine Incorporation Rate}

Bacterial production was estimated by measuring the incorporation of methyl $\left[{ }^{3} \mathrm{H}\right]$-thymidine (TdR) into material precipitated by ice-cold trichloroacetic acid (TCA; Fuhrman and Azam 1982). Ten-mL sub- 
TABLE 1. Summary of empirical conversion factors for calculating bacterial production from thymidine (TdR) incorporation rates. Site LR-3 was $3.8 \mathrm{~km}$ offshore from the mouth of the Lester River. NOAA-3 was in the Chefswet Basin of Lake Superior (see Fig. 1).

\begin{tabular}{|c|c|c|c|c|}
\hline Site & Date & $\begin{array}{l}\text { Depth } \\
(\mathrm{m})\end{array}$ & $\begin{array}{c}\text { Incubation } \\
\text { Temperature } \\
\left({ }^{\circ} \mathrm{C}\right)\end{array}$ & $\begin{array}{l}\text { Conversion Factor } \\
\left(10^{9} \text { cells/nmol TdR }\right)\end{array}$ \\
\hline Lester River (LR) & $16 / 6 / 89$ & 0.2 & 18 & $\begin{aligned} & 0.36 \\
(\mathrm{n}=4, \mathrm{r}= & 0.98, \mathrm{p}=0.02)\end{aligned}$ \\
\hline \multirow[t]{2}{*}{$\begin{array}{l}\text { Lake Superior } \\
\text { LR-3 }\end{array}$} & $16 / 6 / 89$ & 0.2 & 5 & $\begin{aligned} & 0.80 \\
(\mathrm{n}=3, \mathrm{r}= & 0.93, \mathrm{p}=0.25)\end{aligned}$ \\
\hline & $25 / 7 / 90$ & 0.2 & 15 & $\begin{aligned} & 2.14 \\
(\mathrm{n}=4, \mathrm{r}= & 0.90, \mathrm{p}=0.10)\end{aligned}$ \\
\hline \multirow[t]{2}{*}{ NOAA-3 } & $27 / 8 / 90$ & 5 & 24 & $\begin{aligned} & 0.74 \\
(\mathrm{n}=5, \mathrm{r}= & 0.97, \mathrm{p}=0.01)\end{aligned}$ \\
\hline & $27 / 8 / 90$ & 183 & 24 & $\begin{array}{c}0.39 \\
(\mathrm{n}=4, \mathrm{r}=0.98, \mathrm{p}=0.03)\end{array}$ \\
\hline
\end{tabular}

samples were pipetted into glass scintillation vials along with 5 to $15 \mu \mathrm{Ci}$ of $\mathrm{TdR}(60-80 \mathrm{Ci} / \mathrm{mmol} \mathrm{ICN}$ Radiochemicals, Inc.). We determined in previous experiments that uptake was saturated by these concentrations of thymidine (data not shown). Two subsamples from each depth or time were killed with $37 \%$ formaldehyde $(0.5 \mathrm{~mL})$ and served as the controls. Three live vials were prepared for each sample. Four additional vials were prepared to estimate the effective thymidine pool size by an isotope dilution technique and used to correct for endogenous thymidine (Moriarty and Pollard 1981, Findlay et al. 1984). All vials containing samples were placed in black plastic Mason jars filled with water and suspended at the depth from which they were taken. Laboratory incubations were conducted in the dark at temperatures similar to those in the field. Both field and laboratory samples were incubated for 1-2 $\mathrm{h}$. Incorporation was stopped by adding $10 \mathrm{~mL}$ of ice-cold $10 \%$ TCA and the samples were refrigerated for at least $1 \mathrm{~h}$ or until they could be processed (within 1 week). Prior to filtration, $50 \mu \mathrm{L}$ of a carrier solution $(50 \mu \mathrm{g}$ each of DNA and bovine serum albumin) was added to each vial. Each sample was filtered onto a membrane filter (Millipore, $0.22 \mu \mathrm{m}$ pore) and rinsed three times with several $\mathrm{mL}$ of icecold 5\% TCA. The filters were placed in scintillation vials and dissolved in $1.0 \mathrm{~mL}$ of ethyl acetate before adding $10 \mathrm{~mL}$ of Ecolume or Ecolite ${ }^{+}$(ICN, Inc.) liquid scintillation cocktail and counting radioactive decay (Packard model 2200CA liquid scintillation counter). Sample counts were corrected for quenching using external standards and isotope dilution before they were converted to $\mathrm{pmol} \mathrm{TdR}$ incorporated/ $\mathrm{L} / \mathrm{h}$.

\section{Data Analysis}

Differences in bacterioplankton abundance, cell biovolume, or thymidine incorporation on different dates, or at different sites or depths from which samples were taken were determined by one-way and two-way analyses of variance (Wilkinson 1989b). Relationships between temperature or chemical parameters and bacterioplankton abundance, biovolume, and production were tested using linear regression or correlation analysis (Wilkinson 1989b).

\section{Experiments Relating Thymidine Incorporation to Cell Production}

Growth experiments were conducted on four occasions to determine the relationship between bacterial cell production and thymidine incorporation (Kirchman et al. 1982). Water for these experiments was collected from three sites (LR, LR-3, NOAA-3) on three different dates by methods described earlier (Table 1). One portion of water $(900 \mathrm{~mL})$ from each sample was filtered $(0.2 \mu \mathrm{m})$ to remove bacteria and added to a sterilized flask. A smaller amount (100 $\mathrm{mL})$ of "predator-free" water $(0.8 \mu \mathrm{m}$ filtered $)$ con- 
taining native bacterioplankton was then added to the same flask. Three replicate flasks were prepared for each Lester River and LR-3 experiment. Single flasks were used for experiments in the Chefswet basin (site NOAA-3, 5 and $183 \mathrm{~m}$ ). Typically, these flasks were prepared and the experiments initiated within 1 to 4 hours after the water was collected. After adding the "predator-free" water to each flask, the growth of bacterial cells was measured five times over a period of 2-3 d using direct counts and thymidine incorporation. A conversion factor relating cell production and thymidine uptake was then calculated using the equations of Kirchman et al. (1982).

The empirical conversion factors calculated for the western arm of Lake Superior (Table 1) were similar to factors derived by theoretical methods (e.g., $\sim 1$ to $2 \times 10^{9}$ cells/nmol, Bell 1990). Many studies have used theoretical conversion factors for estimating bacterial production but empirical conversion factors can range over two orders of magnitude in freshwater environments (Hwang and Heath 1997). For example, the conversion factors we calculated $\left(0.4\right.$ to $2.1 \times 10^{9}$ cells $\left./ \mathrm{nmol}\right)$ were slightly smaller than those estimated for Lake Erie bacterioplankton during the summer $\left(0.4\right.$ to $24 \times 10^{9}$ cells/nmol, Hwang and Heath 1997) but were at least an order of magnitude smaller than empirical factors calculated for Lake Michigan (Scavia and Laird 1987). The reasons for differences in empirical conversion factors have been thoroughly discussed by others (Bell 1990, Cho and Azam 1988, Jeffrey and Paul 1988, Hwang and Heath 1997). Less severe nutrient limitation in Lakes Erie and Michigan may be reflected in higher conversion factors found there compared to Lake Superior (Bell 1990, Fallon and Boylen 1990). We calculated empirical conversion factors for the western portion of Lake Superior so that bacterial cell production could be estimated accurately from our thymidine incorporation rates.

\section{RESULTS}

\section{Temporal Changes and Spatial Differences at a Nearshore Site (LR-3) in the Duluth Basin}

Each year during May, the water column was isothermal at site LR-3 in the Duluth basin. After July, the water column became thermally stratified ranging from $14^{\circ} \mathrm{C}$ to $19^{\circ} \mathrm{C}$ at the surface to $4^{\circ} \mathrm{C}$ to $6^{\circ} \mathrm{C}$ near the sediment (Fig. 2). The mass of suspended solids was similar in the epilimnion over the course of each year (Fig. 2) but increased near the sediment-water interface during July and August in-
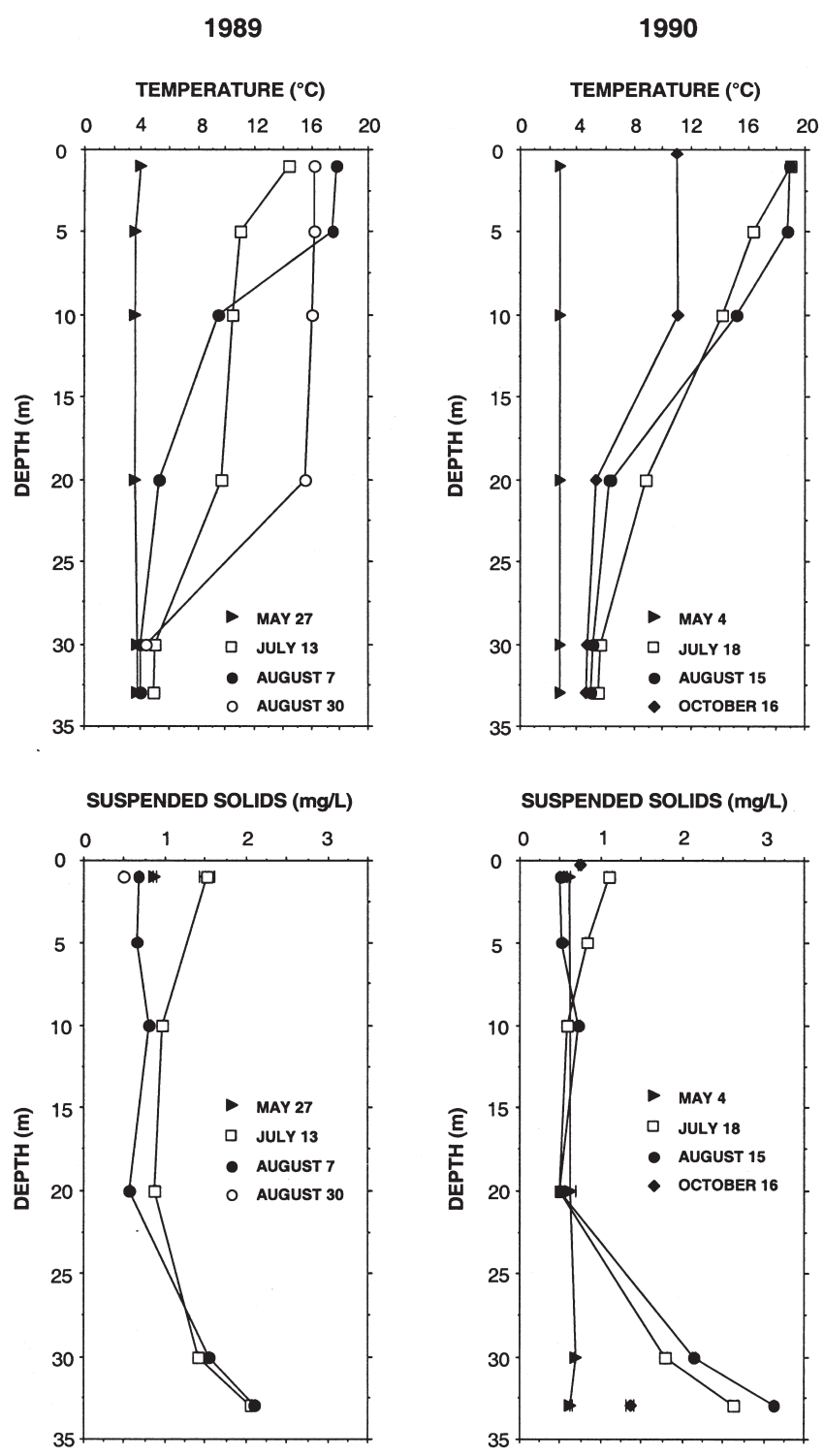

FIG. 2. Vertical profiles of temperature and suspended solids at site LR-3 in the Duluth basin during 1989 and 1990. Note the turbid bottom water layer (benthic nepheloid layer) that formed during July and August each year at this site.

dicating the development of a benthic nepheloid layer (BNL; all p's < 0.05).

\section{Annual and Seasonal Differences in the Bacterioplankton Community}

Disregarding changes with depth, there were annual differences in bacterioplankton abundance at site LR-3 in the Duluth basin (Fig. 3). Considering May to October, bacteria were more abundant $(\mathrm{p}<$ 

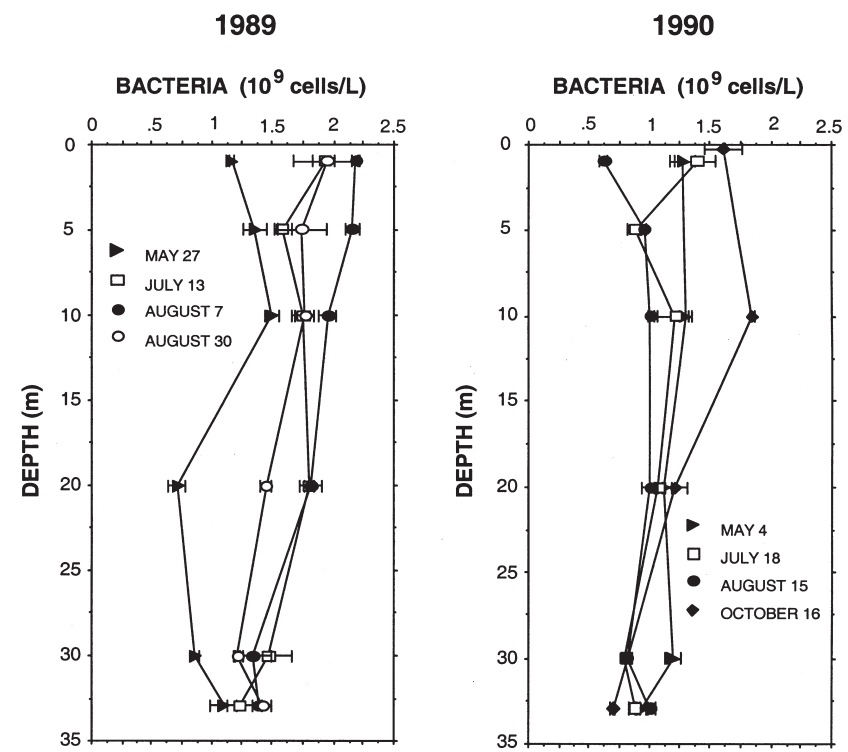

FIG. 3. Bacterioplankton abundance at site LR3 in the Duluth basin during 1989 and 1990. Depth profiles from June each year, 13 Oct 89, and 25 Sept 90 were not shown for clarity. Means of three replicate measurements ( \pm standard error) are shown.

$0.01)$ in the water column during $1989(1.48[ \pm 0.06$ $\mathrm{SE}] \times 10^{9}$ cells $/ \mathrm{L}$, range $=0.71$ to $2.17 \times 10^{9}$ cells $\left./ \mathrm{L}\right)$ than in $1990\left(1.14[ \pm 0.06 \mathrm{SE}] \times 10^{9}\right.$ cells $/ \mathrm{L}$, range $=$ 0.62 to $1.84 \times 10^{9}$ cells/L). Bacteria were also usually more abundant at each depth during 1989 . The only exception was that in both years bacterial abundances were similar (all p's $>0.05$ ) at most depths during May (except at $20 \mathrm{~m}$ ), before the water column became thermally stratified. Bacterial cells were also larger $(p<0.01)$ at site LR-3 during 1989 $\left(0.067[ \pm 0.007 \mathrm{SE}] \mu \mathrm{m}^{3}\right)$ than in $1990(0.025[ \pm$ $\left.0.002 \mathrm{SE}] \mu \mathrm{m}^{3}\right)$. Cell biovolumes were only similar during July of these two years (data not shown; $p>$ 0.05). Cell biovolume was weakly correlated with bacterial abundance $\left(\mathrm{r}^{2}=0.2, \mathrm{p}<0.01\right)$. When bacterioplankton were more abundant, cell biovolumes were usually larger. On an annual basis, the percentages of coccoid-, rod-, and vibrio-shaped cells were almost identical in 1989 and 1990 (Fig. 4). Sixtyfour percent (1990) to 65\% (1989) of the total cells were cocci, $28 \%$ (1989) to $29 \%$ (1990) were rods, and $7 \%$ of the total cells each year were vibrioshaped. Only a few bacterioplankton each year were filaments $(0.2-0.6 \%)$ or spiral-shaped cells $(0.2 \%$ both years). There were no consistent annual or seasonal patterns of thymidine incorporation during
1989 and 1990 (Fig. 5). Although the rate of thymidine incorporation varied from 0.2 to $47.2 \mathrm{pmol} / \mathrm{L} / \mathrm{h}$ at site LR-3 during these years, the rates of incorporation at each depth were similar each month and year (all p's $>0.05$ ). The average incorporation rate at LR-3 was $12.1( \pm 1.3 \mathrm{SE}) \mathrm{pmol} / \mathrm{L} / \mathrm{h}$ considering all depths and both years.

Seasonal changes in bacterial measurements were less pronounced within each year than the annual differences between 1989 and 1990. Considering 1989 alone, bacterioplankton were least abundant during May but similar during other months (Fig. 3). Cell abundances were similar at each depth during the other months of this year (p's > 0.05). During 1990 , bacterioplankton abundance was also very similar from month to month with two exceptions. There were fewer cells at $1 \mathrm{~m}$ during August than in October $(\mathrm{p}<0.05)$ and at $10 \mathrm{~m}$ there were more bacterioplankton during October than in any other month (p's < 0.05). Cell biovolumes were usually similar during each month from May to October in 1989 and 1990 (data not shown; $\mathrm{p}<0.05$ ). The only exception to this pattern was that cell biovolumes were smaller in early summer (May, July) than in August during 1989. There was no significant month-to-month variation in the thymidine incorporation rate at site LR-3 during 1989 and 1990 (Fig. 5).

\section{Changes with Depth at Site LR-3}

During both 1989 and 1990, bacterioplankton abundance changed with depth each month, generally decreasing from the epilimnion to the hypolimnion (Fig. 3, all p's < 0.05). Cell biovolumes were similar at all depths during each month in both 1989 and 1990 (data not shown, all p's > 0.05). Considering the entire water column, the rate of thymidine incorporation only decreased with depth at site LR-3 on 30 Aug 1989 and 16 Oct 1990 (Fig. 5, both p's < 0.05). There were no differences in the rate of thymidine incorporation at different depths during the other months examined each year.

During July and August each year, suspended solids concentrations increased from $20 \mathrm{~m}$ to the sediment-water interface (Fig. 2; all p's $<0.01$ ) indicating that a benthic nepheloid layer (BNL) had formed at site LR-3. The presence of a BNL could not be established on 30 Aug 1989 because suspended solids concentrations were not measured. Only on 15 Aug 1990, however, did bacterioplankton abundance increase near the sediment-water interface (all p's $<0.10$ ) concurrently with the increase in 

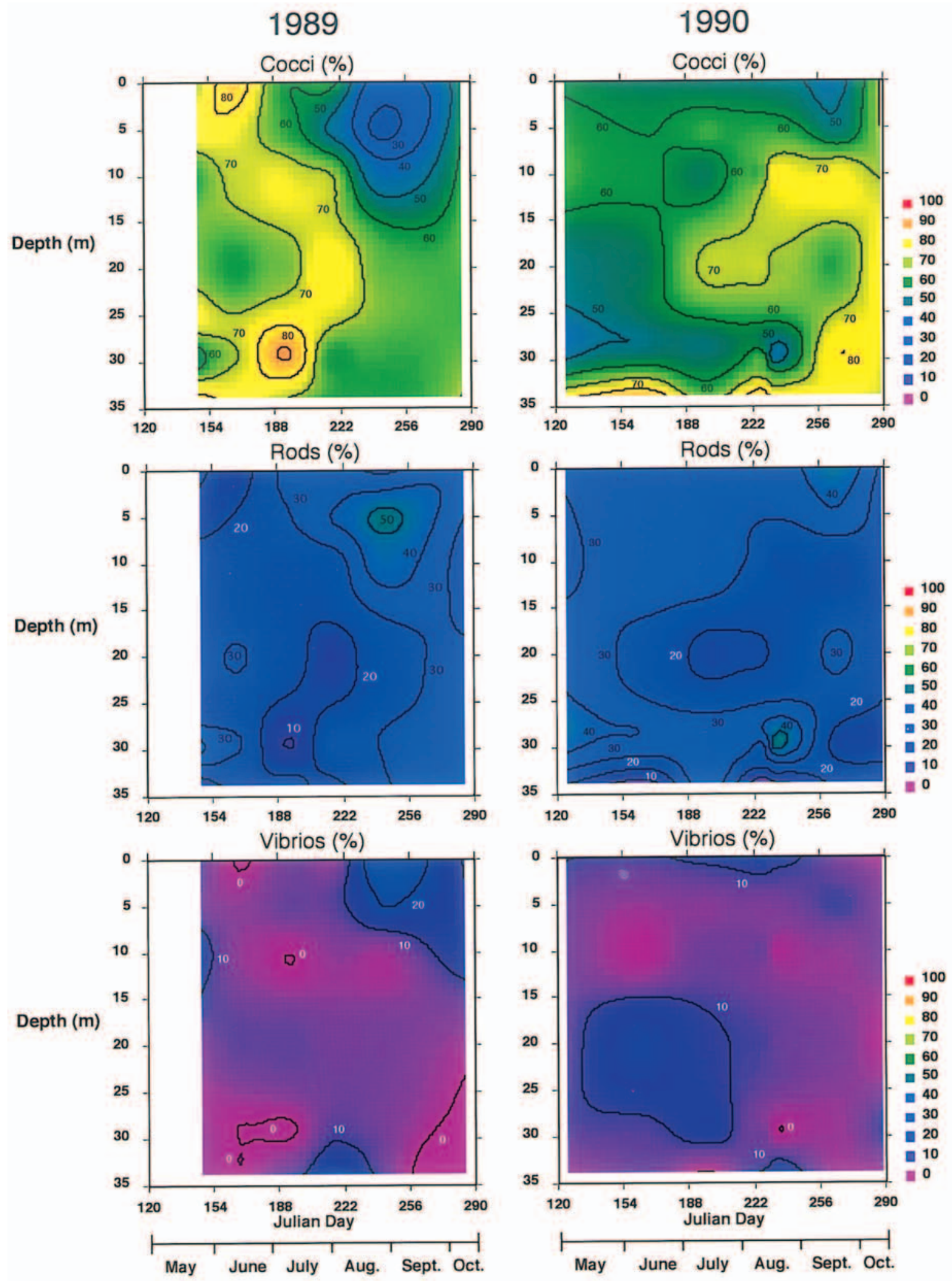

FIG. 4. Contour scatterplots of relative abundances of major bacterioplankton cell shapes in 1989 and 1990 at site LR-3 in the Duluth basin of Lake Superior. Contour lines are percentages of total bacterioplankton cells. Typically, five depths were sampled on six different dates each year. The shapes of 13 to 101 cells were categorized at each depth during 1989 (34 sample points) and 1990 (38 sample points). Thus, more than 1,280 cells were analyzed in 1989 and more than 1,795 cells in 1990 to construct these plots. 
1989

THYMIDINE INCORPORATION (pmol/L/h)

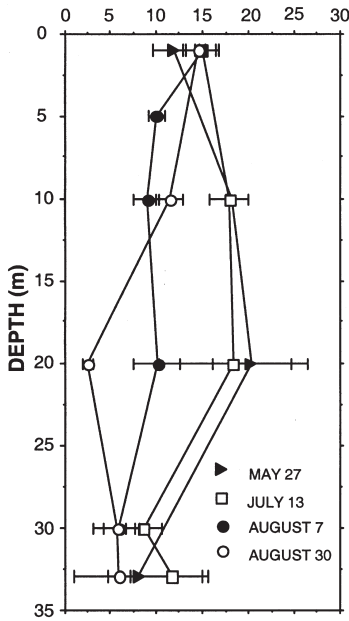

1990

THYMIDINE INCORPORATION (pmol/L/h)

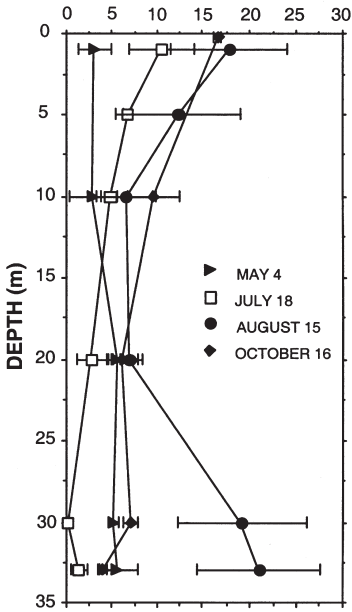

FIG. 5. Thymidine incorporation rates at site LR-3 in the Duluth basin during 1989 and 1990. Depth profiles for June each year, 13 Oct 89, and 25 Sept 90 were not shown for clarity. Means of three replicate measurements ( \pm standard error) are shown.

suspended solids. Although the rate of thymidine incorporation appeared to increase near the sedimentwater interface as well, the data were too variable to demonstrate a significant trend (Fig. 5). On the other dates (i.e., 13 Jul 89, 7 Aug 89, and 18 Jul 90), bacterial abundance decreased near the sediment-water interface (Fig. 3; all p's < 0.10). On the same dates in July and August, cell biovolumes and thymidine incorporation rates were not different between $20 \mathrm{~m}$ and the sediment-water interface (all p's $>0.10$ ).

Relationships between Temperature, Organic Carbon, and Bacterial Measurements at LR-3

Relationships between temperature, organic carbon, and bacterial measurements were explored at site LR-3 in both 1989 and 1990. More bacterioplankton were observed in warm than in cool water during 1989 at this nearshore site (Fig. 6; $\mathrm{r}^{2}=0.61$, $\mathrm{p}<0.01$ ). During 1990, however, abundance was not related to water temperature and thus, this relationship was weaker when data from both 1989 and 1990 were considered together $\left(\mathrm{r}^{2}=0.17, \mathrm{p}<0.01\right)$. Cell biovolume was also related to water temperature in $1989\left(\mathrm{r}^{2}=0.35, \mathrm{p}<0.01\right)$ but not in 1990 (Fig. 6). Thymidine incorporation was only weakly related to temperature $\left(\mathrm{r}^{2}=0.13, \mathrm{p}<0.05\right)$ from May to Octo- ber during 1990. There was not a significant relationship between temperature and the rate of thymidine incorporation during 1989 (Fig. 6).

Bacterioplankton abundance and the rate of thymidine incorporation were not related to the concentration of suspended solids during 1989 or 1990 (Fig. 6). There was no relationship between suspended solids and cell biovolume in 1989. However, cell biovolumes were smaller as the concentration of suspended solids increased in $1990\left(\mathrm{r}^{2}=0.17, \mathrm{p}<0.05\right)$. Interestingly, bacterial abundance, cell biovolume, and thymidine incorporation were not related to either the concentrations of DOC or POC each year (Fig. 7; all p's > 0.05).

\section{Nearshore and Inter-basin Differences in the Western Arm of Lake Superior}

Comparison of the Lester River (LR) and a Nearshore Site (LR-3) in the Duluth Basin

The mouth of the Lester River (LR) was sampled on seven occasions during 1989 and 1990 to compare with the nearest site in Lake Superior (LR-3). On each date, suspended solids, DOC, and POC concentrations were much larger at the river mouth than at site LR-3 $(3.8 \mathrm{~km}$ from the mouth of the Lester River). Suspended solids and POC were more than twice as concentrated in the river mouth than offshore (both p's < 0.01) considering all the dates when samples were taken (Table 2). The average DOC concentration was more than 5 times higher in the river mouth than at LR-3 ( $\mathrm{p}<0.01)$. Measurements of bacterial abundance and production were also consistently higher at the mouth of the Lester River compared to LR-3. Overall, bacteria were about twice as abundant in the river mouth $(\mathrm{p}<$ 0.05 ) and the rate of thymidine incorporation was almost 10 times higher $(\mathrm{p}<0.01)$ than at LR-3 (Table $3)$. Interestingly, the average biovolume of bacterial cells was similar in water from the river mouth and site LR-3 ( $p>0.05)$.

Differences at Offshore Sites in the Duluth and Chefswet Basins of Lake Superior

Three sites in addition to LR-3 were visited in the western portion of Lake Superior during late August 1990 to investigate spatial differences in bacterioplankton abundance and production. The sites in the Duluth basin (LR-3, SG-S, SG-D) formed a transect extending $47 \mathrm{~km}$ northeast along the western arm from the first site (LR-3) near Duluth, MN. There was more DOC in the epilimnion at the Duluth basin 
Hicks et al.


FIG. 6. Relationships between temperature, suspended solids, bacterioplankton abundance, bacterial biovolume, and the rate of thymidine incorporation at site LR-3 in the Duluth basin during $1989(\bullet)$ and $1990(\bigcirc)$. Means of replicate measurements are shown for all sample dates. 

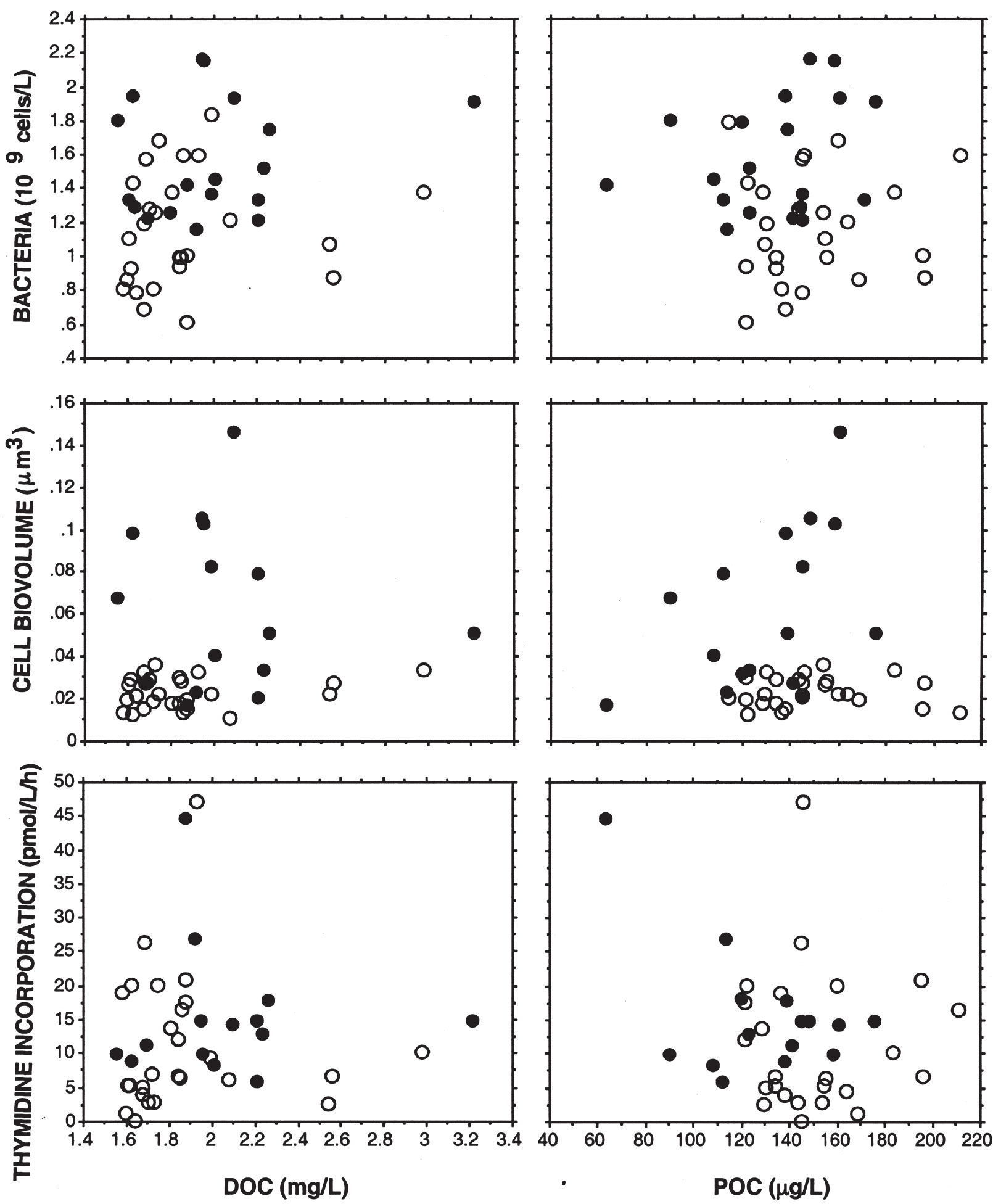

FIG. 7. Relationships between dissolved organic carbon (DOC), particulate organic carbon (POC), bacterioplankton abundance, bacterial biovolume, and the rate of thymidine incorporation at site LR-3 in the Duluth basin during $1989(\bullet)$ and $1990(\bigcirc)$. Means of replicate measurements are shown for all sample dates. 
TABLE 2. Physical and chemical characteristics of water at the mouth of the Lester River (LR) and $3.8 \mathrm{~km}$ offshore at site LR-3 in the western arm of Lake Superior. The mean of independent replicates is given $(n=1$ to $3 ; n d=n o t$ determined). Standard errors of the mean are shown in parentheses. Lester River samples were taken at $0.2 \mathrm{~m}$. Samples taken at $1 \mathrm{~m}$ or averaged over the entire water column (an average of samples from 5-6 depths) are given for site LR-3. Site averages with the same superscript letter were significantly different $(p<0.05)$.

\begin{tabular}{|c|c|c|c|c|c|}
\hline Site & Date & $\begin{array}{c}\text { Temperature } \\
\left({ }^{\circ} \mathrm{C}\right)\end{array}$ & $\begin{array}{l}\text { Suspended } \\
\text { Solids } \\
\text { (mg/L) }\end{array}$ & $\begin{array}{c}\text { Particulate } \\
\text { Organic } \\
\text { Carbon } \\
(\mu \mathrm{g} \mathrm{C} / \mathrm{L})\end{array}$ & $\begin{array}{c}\text { Dissolved } \\
\text { Organic } \\
\text { Carbon } \\
(\mathrm{mg} \mathrm{C} / \mathrm{L})\end{array}$ \\
\hline \multicolumn{6}{|c|}{ LESTER RIVER (0.2 m) } \\
\hline \multirow[t]{8}{*}{ LR } & 17 Jun 89 & 13.1 & $2.55(0.10)$ & $308(8)$ & nd \\
\hline & 12 Jul 89 & 18.6 & $2.77(0.02)$ & $263(3)$ & 11.90 \\
\hline & 8 Aug 89 & 29.0 & $4.89(0.37)$ & $430(12)$ & 8.47 \\
\hline & 6 Sep 89 & 19.0 & $2.16(0.11)$ & $145(5)$ & 14.15 \\
\hline & 4 May 90 & nd & $3.17(0.19)$ & 294 (13) & 15.75 \\
\hline & 15 Aug 90 & nd & $1.67(0.02)$ & $325(26)$ & 7.66 \\
\hline & 25 Sep 90 & 14.5 & $1.31(0.02)$ & $127(1)$ & 16.85 \\
\hline & $\begin{array}{l}\text { AVERAGE } \\
\text { SE }\end{array}$ & $\begin{array}{l}18.8^{\mathrm{a}} \\
(2.8)\end{array}$ & $\begin{array}{l}2.64 \mathrm{bc} \\
(0.45)\end{array}$ & $\begin{array}{l}289 \mathrm{de} \\
(34)\end{array}$ & $\begin{array}{l}12.46^{\mathrm{fg}} \\
(1.55)\end{array}$ \\
\hline \multicolumn{6}{|c|}{ LR-3 (1 m) } \\
\hline \multirow[t]{9}{*}{ LR-3 } & 15 Jun 89 & 6.0 & $0.84(0.06)$ & $122(10)$ & 2.23 \\
\hline & 13 Jul 89 & 14.4 & $1.51(0.09)$ & $175(4)$ & 3.21 \\
\hline & 7 Aug 89 & 17.7 & $0.68(0.01)$ & $148(1)$ & 1.94 \\
\hline & 30 Aug 89 & 16.2 & $0.49(0.01)$ & $161(5)$ & 2.09 \\
\hline & 4 May 90 & 2.8 & $0.60(0.02)$ & $153(1)$ & 1.72 \\
\hline & 15 Aug 90 & 18.9 & $0.49(0.01)$ & $121(10)$ & 1.87 \\
\hline & 25 Sep 90 & 14.4 & $0.58(0.03)$ & $146(7)$ & 1.93 \\
\hline & AVERAGE & 12.9 & $0.74^{b}$ & $146^{\mathrm{d}}$ & $2.14^{\mathrm{f}}$ \\
\hline & SE & (2.3) & $(0.14)$ & (7) & $(0.19)$ \\
\hline \multirow{9}{*}{ LR-3 } & & LR-3 (Entire V & lumn $-1 \mathrm{~m} \mathrm{t}$ & & \\
\hline & 15 Jun 89 & $4.5(0.4)$ & $0.94(0.13)$ & $111(17)$ & $2.06(0.09)$ \\
\hline & 13 Jul 89 & $9.2(1.5)$ & $1.35(0.21)$ & $136(12)$ & $2.29(0.33)$ \\
\hline & 7 Aug 89 & $9.6(2.6)$ & $1.06(0.25)$ & $131(10)$ & $1.88(0.10)$ \\
\hline & 30 Aug 89 & $13.7(2.3)$ & $0.49(\mathrm{nd})$ & $161(\mathrm{nd})$ & 2.09 (nd) \\
\hline & 4 May 90 & $2.8(0.0)$ & $0.63(0.01)$ & $143(5)$ & $1.66(0.02)$ \\
\hline & 15 Aug 90 & $11.5(2.8)$ & $1.25(0.46)$ & $143(11)$ & $1.80(0.05)$ \\
\hline & 25 Sep 90 & $12.2(1.0)$ & $0.71(0.08)$ & $136(7)$ & $1.75(0.05)$ \\
\hline & $\begin{array}{c}\text { AVERAGE } \\
\text { SE }\end{array}$ & $\begin{array}{r}9.2^{\mathrm{a}} \\
(0.9)\end{array}$ & $\begin{array}{r}0.98^{c} \\
(0.11)\end{array}$ & $\begin{array}{r}135^{\mathrm{e}} \\
(4)\end{array}$ & $\begin{array}{r}1.89 \mathrm{~g} \\
(0.06)\end{array}$ \\
\hline
\end{tabular}

sites $(\mathrm{p}<0.05)$ than at the site furthest offshore in the Chefswet basin (NOAA-3) but DOC concentrations were similar in the hypolimnion and near the sediment at all of these sites (Table 4). Suspended solids concentrations were higher in the hypolimnion and near the sediment surface at the shallower sites, LR-3 and SG-S, than at the deeper sites SG-D and NOAA-3, which are further offshore (Table 4; p's <
0.05). This difference was due to a BNL that had formed at LR-3 in August 1989 (Fig. 2). A BNL also appeared to be present at site SG-S on 1 Sept 90 because suspended solids were higher above the sediment than in the hypolimnion (Table 4), the organic content of suspended solids near the sediment (i.e., 9\%) were typical of BNLs in the western arm of Lake Superior (ca. 10\%, Baker et al. 1985), and the 
TABLE 3. Comparison of bacterioplankton abundance, cell biovolume, and thymidine incorporation rate at the mouth of the Lester River $(L R)$ and $3.8 \mathrm{~km}$ offshore at site LR-3 in the western arm of Lake Superior. The mean of independent replicates is given $(n=1$ to 3; $n d=$ not determined). Standard errors of the mean are shown in parentheses. Lester River samples were taken at $0.2 \mathrm{~m}$. Samples taken at $1 \mathrm{~m}$ or averaged over the entire water column (an average of samples from 5-6 depths) are given for site LR-3. Site averages with the same superscript letter were significantly different $(p<0.05)$.

\begin{tabular}{|c|c|c|c|c|}
\hline Site & Date & $\begin{array}{l}\text { Bacterial } \\
\text { Abundance } \\
\left(10^{9} \text { cells } / \mathrm{L}\right)\end{array}$ & $\begin{array}{l}\text { Cell } \\
\text { Biovolume } \\
\left(\mu \mathrm{m}^{3}\right)\end{array}$ & $\begin{array}{l}\text { Thymidine } \\
\text { Incorporation } \\
\text { (pmol/L/h) }\end{array}$ \\
\hline \multicolumn{5}{|c|}{ LESTER RIVER $(0.2 \mathrm{~m})$} \\
\hline \multirow[t]{8}{*}{ LR } & 17 Jun 89 & $3.11(0.06)$ & $0.031(0.004)$ & $95.7(4.9)$ \\
\hline & 12 Jul 89 & $3.10(0.38)$ & $0.066(0.012)$ & $421.3(14.6)$ \\
\hline & 8 Aug 89 & $5.37(0.42)$ & $0.090(0.003)$ & $336.9(48.3)$ \\
\hline & 6 Sep 89 & $1.91(0.04)$ & nd & $101.5(2.7)$ \\
\hline & 4 May 90 & $1.39(0.03)$ & $0.026(0.003)$ & nd \\
\hline & 15 Aug 90 & $3.29(0.05)$ & $0.031(0.004)$ & $205.0(18.4)$ \\
\hline & 25 Sep 90 & $1.91(0.08)$ & $0.047(0.017)$ & $120.8(14.3)$ \\
\hline & $\begin{array}{c}\text { AVERAGE } \\
\text { SE }\end{array}$ & $\begin{array}{l}2.87^{\mathrm{ab}} \\
(0.50)\end{array}$ & $\begin{array}{c}0.049 \\
(0.010)\end{array}$ & $\begin{array}{c}213.5^{\mathrm{cd}} \\
(55.8)\end{array}$ \\
\hline \multirow{9}{*}{ LR-3 } & \multicolumn{3}{|c|}{ LR-3 (1 m) } & \\
\hline & 15 Jun 89 & $1.53(0.09)$ & $0.034(0.001)$ & $13.0(2.1)$ \\
\hline & 13 Jul 89 & $1.92(0.09)$ & $0.051(0.005)$ & $15.0(1.9)$ \\
\hline & 7 Aug 89 & $2.17(0.03)$ & $0.106(0.008)$ & $15.0(0.3)$ \\
\hline & 30 Aug 89 & $1.95(0.27)$ & $0.147(\mathrm{nd})$ & $14.6(1.8)$ \\
\hline & 4 May 90 & $1.27(0.11)$ & $0.037(0.019)$ & $3.1(1.8)$ \\
\hline & 15 Aug 90 & $0.62(0.03)$ & $0.020(0.006)$ & $17.7(6.3)$ \\
\hline & 25 Sep 90 & $1.60(0.05)$ & $0.033(0.008)$ & $47.2(0.0)$ \\
\hline & $\begin{array}{c}\text { AVERAGE } \\
\text { SE }\end{array}$ & $\begin{array}{c}1.58^{\mathrm{a}} \\
(0.20)\end{array}$ & $\begin{array}{c}0.061 \\
(0.018)\end{array}$ & $\begin{array}{l}17.9^{\mathrm{c}} \\
(5.2)\end{array}$ \\
\hline \multirow{9}{*}{ LR-3 } & \multicolumn{3}{|c|}{ LR-3 (Entire Water Column -1 m to $33 \mathrm{~m}$ ) } & \\
\hline & 15 Jun 89 & $1.30(0.08)$ & $0.026(0.003)$ & $25.0(5.6)$ \\
\hline & 13 Jul 89 & $1.62(0.10)$ & $0.040(0.004)$ & $14.3(1.9)$ \\
\hline & 7 Aug 89 & $1.80(0.15)$ & $0.090(0.006)$ & $10.0(1.5)$ \\
\hline & 30 Aug 89 & $1.59(0.11)$ & $0.114(0.010)$ & $8.0(2.2)$ \\
\hline & 4 May 90 & $1.16(0.06)$ & $0.031(0.002)$ & $4.5(0.6)$ \\
\hline & 15 Aug 90 & $0.90(0.06)$ & $0.021(0.003)$ & $13.9(2.6)$ \\
\hline & 25 Sep 90 & $1.58(0.06)$ & $0.023(0.003)$ & $25.7(5.7)$ \\
\hline & $\begin{array}{c}\text { AVERAGE } \\
\text { SE }\end{array}$ & $\begin{array}{c}1.43^{b} \\
(0.06)\end{array}$ & $\begin{array}{c}0.050 \\
(0.006)\end{array}$ & $\begin{array}{l}14.5^{\mathrm{d}} \\
(1.7)\end{array}$ \\
\hline
\end{tabular}

water clarity was very low near the sediment when observed from the JSL-II submersible. Suspended solids concentrations in the hypolimnion and near the sediment at sites SG-D and NOAA-3 indicated that benthic nepheloid layers were not present at these deeper, offshore sites (Table 4).

More bacterioplankton were observed in the epil- imnion (p's $<0.05)$ and at the sediment-water interface (both p's $<0.05$ ) at the two shallower sites in the Duluth basin (LR-3 and SG-S) compared to the deeper and more offshore sites examined (Table 5). However in the mid-hypolimnion, bacterioplankton were more concentrated at the Chefswet basin site (NOAA-3) than at two of the sites (LR-3, SG-D) in 
TABLE 4. Physical and chemical characteristics of water from sites in the western portion of Lake Superior. The mean of independent replicates is given $(n=2)$. Standard errors of the mean are shown in parentheses. Site LR-3 was sampled on 15 Aug 1990. SG-S (1 Sept), SGD (31 Aug), and NOAA-3 (27 Aug) were sampled later during 1990.

\begin{tabular}{|c|c|c|c|c|c|}
\hline Site & $\begin{array}{l}\text { Depth } \\
\text { (m) }\end{array}$ & $\begin{array}{c}\text { Temperature } \\
\left({ }^{\circ} \mathrm{C}\right)\end{array}$ & $\begin{array}{c}\text { Suspended } \\
\text { Solids } \\
\text { (mg/L) }\end{array}$ & $\begin{array}{c}\text { Particulate } \\
\text { Organic } \\
\text { Carbon } \\
(\mu \mathrm{g} \mathrm{C} / \mathrm{L})\end{array}$ & $\begin{array}{c}\text { Dissolved } \\
\text { Organic } \\
\text { Carbon } \\
(\mathrm{mg} \mathrm{C} / \mathrm{L})\end{array}$ \\
\hline \multicolumn{6}{|c|}{ EPILIMNION } \\
\hline LR-3 & 5 & 18.7 & $0.52(0.02)$ & $121(16)$ & $1.83(0.03)$ \\
\hline SG-S & 5 & 16.1 & $1.09(0.01)$ & $163(3)$ & $1.95(0.01)$ \\
\hline SG-D & 5 & 14.9 & $0.39(0.01)$ & $159(9)$ & $1.83(0.04)$ \\
\hline NOAA-3 & 5 & 15.2 & $0.38(0.03)$ & $145(10)$ & $1.63(0.00)$ \\
\hline \multicolumn{6}{|c|}{ HYPOLIMNION } \\
\hline LR-3 & 30 & 5.1 & $2.15(0.04)$ & $136(18)$ & $1.57(0.02)$ \\
\hline SG-S & 40 & 7.4 & $0.41(0.01)$ & $132(16)$ & 1.70 \\
\hline SG-D & 40 & 5.3 & $0.25(0.03)$ & $128(2)$ & 1.57 \\
\hline NOAA-3 & 40 & 5.4 & $0.45(0.00)$ & $145(1)$ & 1.64 \\
\hline \multicolumn{6}{|c|}{1 m ABOVE SEDIMENT } \\
\hline LR-3 & 33 & 5.0 & $3.13(0.02)$ & $195(9)$ & 1.87 \\
\hline SG-S & 70 & 4.5 & $1.69(0.21)$ & $160(20)$ & $1.59(0.00)$ \\
\hline SG-D & 163 & 4.2 & $0.43(0.15)$ & $76(19)$ & $1.61(0.01)$ \\
\hline NOAA-3 & 183 & 4.2 & $0.35(0.03)$ & $77(20)$ & $1.74(0.00)$ \\
\hline
\end{tabular}

TABLE 5. Comparison of bacterioplankton abundance, cell biovolume, and thymidine incorporation rate at different sites in the western portion of Lake Superior. The mean of three independent replicates is given. Standard errors of the mean are shown in parentheses. Site LR-3 was sampled on 15 Aug 1990. SG-S (1 Sept), SG-D (31 Aug), and NOAA-3 (27 Aug) were sampled later during 1990.

\begin{tabular}{|c|c|c|c|c|}
\hline Site & $\begin{array}{l}\text { Depth } \\
\text { (m) }\end{array}$ & $\begin{array}{c}\text { Bacterial } \\
\text { Abundance } \\
\left(10^{9} \text { cells } / \mathrm{L}\right)\end{array}$ & $\begin{array}{c}\text { Cell } \\
\text { Biovolume } \\
\left(\mu \mathrm{m}^{3}\right)\end{array}$ & $\begin{array}{l}\text { Thymidine } \\
\text { Incorporation } \\
\text { (pmol/L/h) }\end{array}$ \\
\hline \multicolumn{5}{|c|}{ EPILIMNION } \\
\hline LR-3 & 5 & $0.95(0.03)$ & $0.031(0.010)$ & $12.3(6.9)$ \\
\hline SG-S & 5 & $1.60(0.06)$ & $0.029(0.003)$ & $14.7(2.3)$ \\
\hline SG-D & 5 & $0.67(0.05)$ & $0.026(0.006)$ & $19.1(1.4)$ \\
\hline NOAA-3 & 5 & $0.68(0.02)$ & $0.085(0.003)$ & $16.5(5.5)$ \\
\hline \multicolumn{5}{|c|}{ HYPOLIMNION } \\
\hline LR-3 & 30 & $0.82(0.04)$ & $0.014(0.003)$ & $19.2(7.0)$ \\
\hline SG-S & 40 & $1.17(0.12)$ & $0.027(0.001)$ & $15.0(3.6)$ \\
\hline SG-D & 40 & $0.83(0.04)$ & $0.026(0.006)$ & $12.4(3.3)$ \\
\hline NOAA-3 & 40 & $1.21(0.06)$ & $0.026(0.005)$ & $15.5(12.5)$ \\
\hline \multicolumn{5}{|c|}{1 m ABOVE SEDIMENT } \\
\hline LR-3 & 33 & $1.01(0.04)$ & $0.016(0.003)$ & $21.0(6.7)$ \\
\hline SG-S & 70 & $0.87(0.08)$ & $0.021(0.006)$ & $15.0(7.0)$ \\
\hline SG-D & 163 & $0.50(0.02)$ & $0.028(0.003)$ & $7.2(3.7)$ \\
\hline NOAA-3 & 183 & $0.53(0.04)$ & $0.037(0.013)$ & $7.5(1.5)$ \\
\hline
\end{tabular}


TABLE 6. Bacterioplankton cell shapes in the Duluth and Chefswet basins of Lake Superior. Site LR-3 was sampled on 15 Aug 1990. SG-S (1 Sept), SG-D (31 Aug), and NOAA-3 (27 Aug) were sampled later during 1990.

\begin{tabular}{|c|c|c|c|c|c|c|c|}
\hline Site & $\begin{array}{l}\text { Depth } \\
\text { (m) }\end{array}$ & $\begin{array}{c}\text { Cocci } \\
(\%)\end{array}$ & $\begin{array}{l}\text { Rods } \\
(\%)\end{array}$ & $\begin{array}{c}\text { Vibrios } \\
(\%)\end{array}$ & $\begin{array}{c}\text { Filaments } \\
(\%)\end{array}$ & $\begin{array}{c}\text { Spirals } \\
(\%)\end{array}$ & $\begin{array}{l}\text { Total } \\
\text { Cells }\end{array}$ \\
\hline \multicolumn{8}{|c|}{ EPILIMNION } \\
\hline LR-3 & 5 & 62.9 & 30.6 & 4.8 & 1.6 & 0 & 62 \\
\hline SG-S & 5 & 71.2 & 26.9 & 1.9 & 0 & 0 & 52 \\
\hline SG-D & 5 & 62.5 & 29.7 & 7.8 & 0 & 0 & 64 \\
\hline NOAA-3 & 5 & 56.1 & 40.4 & 1.8 & 0 & 0 & 57 \\
\hline \multicolumn{8}{|c|}{ HYPOLIMNION } \\
\hline LR-3 & 30 & 67.4 & 25.6 & 7.0 & 0 & 0 & 43 \\
\hline SG-S & 40 & 72.0 & 24.0 & 2.0 & 2.0 & 0 & 50 \\
\hline SG-D & 40 & 61.3 & 30.6 & 8.1 & 0 & 0 & 62 \\
\hline NOAA-3 & 40 & 74.3 & 21.8 & 4.0 & 0 & 0 & 101 \\
\hline \multicolumn{8}{|c|}{$1 \mathrm{~m}$ ABOVE SEDIMENT } \\
\hline LR-3 & 33 & 79.2 & 12.5 & 8.3 & 0 & 0 & 24 \\
\hline SG-S & 70 & 77.5 & 20.0 & 2.5 & 0 & 0 & 40 \\
\hline SG-D & 163 & 76.9 & 19.2 & 3.8 & 0 & 0 & 52 \\
\hline NOAA-3 & 183 & 87.5 & 8.3 & 4.2 & 0 & 0 & 24 \\
\hline
\end{tabular}

the Duluth basin (both p's < 0.05). At the two shallower sites where a BNL was present (LR-3 and SG$\mathrm{S})$, bacterioplankton were only more abundant near the sediment-water interface at site LR-3 ( $\mathrm{p}<0.05)$. Bacteria were less abundant near the sediment-water interface than in the epilimnion or hypolimnion at the deeper sites (SG-D and NOAA-3; both p's < $0.05)$. This pattern could be related to the absence of a BNL at these sites.

Like site LR-3, most bacterioplankton were cocci in other areas of the western portion of Lake Superior (Table 6). Coccoid-shaped cells appeared to be more common near the sediment surface and rodshaped cells were more common in the epilimnion and hypolimnion at these sites (Table 6). Epilimnetic cell volumes were similar at sites in the Duluth basin ( $p>0.05)$, but these cells were smaller than cells in the epilimnion at site NOAA-3 (Table 2, all p's < $0.05)$. Cell biovolumes were not different in the hypolimnion and above the sediment surface at all sites examined (all p's $>0.05$ ).

The rate of thymidine incorporation was similar at all sites when samples from the epilimnion, hypolimnion, and above the sediment surface were compared (Table 5; all p's $>0.05$ ). The rates of thymidine incorporation were similar in the hypolimnion and near the sediment-water interface at the shallower sites where a BNL was present (p's < $0.05)$. Although the thymidine incorporation rate ap- peared to be lower near the sediment at the deeper offshore sites (SG-D, NOAA-3), these rates were not significantly different from rates measured in the hypolimnion at these sites (p's $>0.05$ ). Overall, no differences in the rate of thymidine incorporation were detected at the Duluth basin or Chefswet basin sites. Considering all sites and depths, the average rate of thymidine incorporation was $14.6( \pm 1.2 \mathrm{SE})$ $\mathrm{pmol} / \mathrm{L} / \mathrm{h}$ along this transect (Table 5).

\section{DISCUSSION}

\section{Interannual Variability at a Shallow Nearshore Site in the Duluth Basin}

Bacterioplankton abundances in the western arm of Lake Superior were similar to those reported for marine systems and other Laurentian Great Lakes as well as another region of Lake Superior (Auer and Powell 2004). Seasonal changes in bacterioplankton abundance and production have been observed in Lake Michigan (Scavia and Laird 1987, Pernie et al. 1990). Similarly, seasonal differences in the number of culturable heterotrophic bacteria in the surface waters of Lake Superior have also been observed (Rao 1978). Like these previous studies, there were changes in bacterial abundance at site LR-3 in the western arm of Lake Superior due to the year examined and the depth from which samples were taken. Bacterial cell volume and the rate of thymidine in- 
corporation, however, did not change consistently with season or depth at this site.

Overall, the most striking feature of the data from LR-3 was that bacterioplankton were more abundant and the cells were larger from May to October during 1989 than in 1990 (Fig. 3, Table 3). These differences may be related to temperature (Fig. 6). Bacterioplankton abundance and cell biovolume were both positively correlated with temperature in 1989 but not in 1990 (Fig. 6). There are often strong relationships between temperature and bacterial production as well as cell abundance in aquatic environments including the Laurentian Great Lakes (Scavia and Laird 1987, Hicks and Owen 1991, White et al. 1991). However, the rate of thymidine incorporation was only weakly related to temperature at site LR-3 and only during 1990 (Fig. 6).

Cole et al. (1988) demonstrated that bacterial production estimated by a variety of methods was correlated with primary production suggesting that phytoplankton may be an important source of organic substrates to bacterioplankton. It is interesting to compare phytoplankton and bacterial carbon production in Lake Superior during August; a period when bacterial activity is often the highest of the year in the Laurentian Great Lakes (Scavia and Laird 1987, Hwang and Heath 1997, Auer and Powell 2004). During August, phytoplankton production is usually between 1 to $2 \mu \mathrm{g} \mathrm{C} / \mathrm{L} / \mathrm{h}$ in the western arm of Lake Superior (Parkos et al. 1968, Rose 1992). The average rate of thymidine incorporation over the entire water column at LR-3 was $12.1 \mathrm{pmol} / \mathrm{L} / \mathrm{h}$ (Fig. 5) and the average cell biovolume was $0.050 \mu \mathrm{m}^{3}$ (Table 3). If an empirical conversion factor of $0.8 \times$ $10^{9}$ cells/nmol (Table 1) and a carbon conversion factor of $0.25 \mathrm{pg} \mathrm{C} / \mu^{3}$ (Cotner et al. 2000, Psenner 1993) are used, then bacterial carbon production at site LR-3 would average $0.12 \mu \mathrm{g}$ C/L/h or between $6 \%$ and $12 \%$ of primary production in this part of Lake Superior.

Although bacterioplankton abundance and production were not correlated with DOC or POC concentrations from May to October at LR-3 (Fig. 7), these results do not preclude the possibility of bacterioplankton in Lake Superior being dependent on other organic matter sources in addition to phytoplankton at other times of the year. Seasonal drawdowns of DOC, springtime riverine inputs of organic matter, and periodic sediment resuspension probably supplement organic matter from phytoplankton that is available to support bacterioplanktonic production in Lake Michigan (Scavia and Laird 1987, Cotner et al. 2000, Biddanda et al. 2001). Bacterioplankton in
Lake Superior may be even more dependent upon these periodic DOC and POC sources than bacteria in the more productive Great Lakes (Auer and Powell 2004). Unfortunately, we were unable to collect samples when terrestrial inputs probably peaked during the spring runoff period (ca. March and April) to determine if bacterioplankton production and DOC or POC were related at other times of the year.

\section{Influence of a Benthic Nepheloid Layer}

Resuspending sediments can increase bacterioplankton abundances and stimulate the production of planktonic microorganisms (Wainright 1990, Hicks and Owen 1991, Cotner et al. 2000). Data from our study indicate that these changes may not always happen though. During July and August each year, the vertical profile of suspended solids indicated that a benthic nepheloid layer (BNL) had formed at site LR-3 (Fig. 2). On only one of four occasions (e.g., 15 Aug 90) when a BNL was present, however, did bacterioplankton abundance increase significantly near the sediment-water interface (Fig. 3). Also, the rate of thymidine incorporation did not increase near the sediment on any of these occasions, even though it appeared to increase on 15 Aug 90 (Fig. 5). Although a BNL was present at site SG-S, the rate of thymidine incorporation did not increase near the sediment like at LR-3 and bacterioplankton abundance actually decreased near the sediment-water interface (Table 5). Combined, these results indicate that the presence of a BNL does not always indicate a zone of increased bacterioplankton abundance and production. Thus, we must conclude that resuspending sediments may not always increase bacterioplankton abundance or stimulate their production. Other factors in addition to resuspended particles, nutrients and microorganisms probably control bacterioplankton abundance and production in BNLs as well.

\section{Nearshore and Interbasin Differences in the Western Portion of Lake Superior}

\section{Differences between the Lester River (LR) and a Nearshore Site (LR-3)}

It is clear that the chemical and biological characteristics of water at the mouth of the Lester River from May to September were different from the site in Lake Superior (LR-3) that was nearest to the shoreline (Tables 2 and 3). Even though site LR-3 is within $3.8 \mathrm{~km}$ of the mouth of the Lester River, nearshore bacterioplankton did not appear to be 
strongly influenced by this river. Bacterioplankton abundance, cell biovolume, and the rate of thymidine incorporation at LR-3 were more similar to values measured at site SG-S, almost $13 \mathrm{~km}$ away in Lake Superior, than they were to values measured at the Lester River mouth. Although it is a substantial river, the normal discharge of the Lester River from May to September may be too small to impact Lake Superior very far from the shoreline. If samples were taken during the peak of the spring runoff (late March to early April) or immediately after major summer thunderstorms (Robarts 1987), then the impact of this coastal river on nearshore bacterioplankton might be larger.

\section{Inter-basin Differences at Offshore Sites during Late Summer}

The morphology of a lake basin may influence onshore-offshore gradients of productivity in addition to riverine discharge. A shallow depth gradient confines the influence of riverine inputs and provides opportunities for storms to resuspend sediments (Halfman and Johnson 1989, Cotner et al. 2000). Several studies have demonstrated that bacterioplankton abundance and production can decrease from nearshore to offshore areas in Lake Michigan (Moll and Brahce 1986, Scavia and Laird 1987) and Lake Erie (Hwang and Heath 1997, 1999). In these studies, measurements at shallow nearshore sites (sometimes within bays) were compared to much deeper sites further offshore (i.e., 10 to $25 \mathrm{~km}$ from the shoreline).

During late summer, bacterial abundance in our study was also greater at most depths at the shallower sites (i.e., LR-3, SG-S) in Lake Superior compared to the deeper sites further offshore (i.e., SG-D, NOAA-3; Table 5). This pattern was consistent with bacterial abundances decreasing from nearshore to offshore sites in Lakes Michigan and Erie. However, higher rates of thymidine incorporation were not measured at the shallower sites in the western arm of Lake Superior. Nearshore-offshore gradients in bacterial abundance and productivity were rarely observed by Auer and Powell (2004) in 1999 and 2000 along the south shore of Lake Superior. On the few dates that gradients in bacterial abundance and productivity were detected, they did not develop as systematically as nearshore-offshore gradients of temperature or chlorophyll. Water depth increases very quickly with distance from the north shore of Lake Superior compared to the south shore of this lake or to other Laurentian Great Lakes. This geo- morphic difference between the locations of our research sites and the sites of other investigations may explain why strong gradients of bacterial abundance and production were not seen along the transect from sites LR-3 to NOAA-3 in our study. The only true "nearshore" site in our study may have been at the mouth of the Lester River. Thus, it may be more appropriate to compare the results from our Lake Superior sites to the deeper offshore sites in other studies of the Laurentian Great Lakes.

During August 1990, bacterial abundances at the Duluth and Chefswet basin sites $\left(0.5-1.6 \times 10^{9}\right.$ cells/L; Table 5) were similar to abundances measured at offshore sites near the Keweenaw Peninsula of Lake Superior $\left(0.1--1.0 \times 10^{9}\right.$ cells/L; Auer and Powell 2004) but much smaller than abundances measured in Lakes Michigan and Erie. The bacterial abundances we measured were at least two times lower than at an offshore site in Lake Michigan during August ( $2.5 \times 10^{9}$ cells/L; Cotner et al. 2000) and almost an order of magnitude lower than in August at an offshore area in Lake Erie (5.8-6.3 $\times 10^{9}$ cells/L; Hwang and Heath 1999).

Bacterial production in the Duluth and Chefswet basins of Lake Superior was similar to one estimate for Lake Michigan and much smaller than estimates for Lake Erie and another region of Lake Superior. The rate of thymidine incorporation in the Duluth and Chefswet basins in late August and early September averaged $14.6 \mathrm{pmol} / \mathrm{L} / \mathrm{h}$ when all sites and depths were considered (Table 5). If an empirical conversion factor of $0.8 \times 10^{9}$ cells/nmol (Table 1 ), the mean cell biovolume $\left(0.031 \mu^{3}\right.$; Table 5$)$, and a carbon conversion factor of $0.25 \mathrm{pg} \mathrm{C} / \mu \mathrm{m}^{3}$ (Cotner et al. 2000, Psenner 1993) are used, then the average rate of bacterial production at these sites would be $0.09 \mu \mathrm{g} \mathrm{C} / \mathrm{L} / \mathrm{h}$. This rate is similar to the production estimated for an offshore site in Lake Michigan dur-

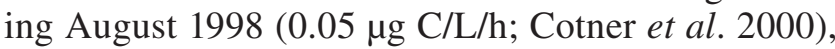
about 1.5 to 5 times more than production measured off the Keweenaw Peninsula (0.02 to $0.06 \mu \mathrm{g} \mathrm{C} / \mathrm{L} / \mathrm{h}$; Auer and Powell 2004), and 1.7 to 10 times less than bacterial production at an offshore site in Lake Erie during August 1993 and 1994 (0.15 and $0.91 \mu \mathrm{g}$ C/L/h, respectively; Hwang and Heath 1999).

In conclusion, bacterioplankton abundance demonstrated the most pronounced temporal and spatial differences in the western arm of Lake Superior compared to cell biovolume and production. Although some seasonal changes in bacterioplankton abundance were observed at a nearshore site in the Duluth basin (LR-3), the greatest differences were the changes in cell abundance and biovolume be- 
tween 1989 and 1990 at this site. These changes may be related to temperature but bacterial abundance, biovolume, and production were not related to DOC or POC concentrations in either year. Bacteria were more abundant and productive at the mouth of the Lester River than at the nearest offshore site in Lake Superior, indicating that this river may have limited influence on offshore bacterioplankton communities at least over the period of our study. During July and August, a benthic nepheloid layer formed at the shallower sites in the western arm of Lake Superior but bacterial abundance and production were not always higher in this BNL. Although bacterial abundances were often greater at the shallower sites compared to the deeper sites further offshore during late summer, a strong gradient was not found and no change in bacterial production was observed. These results may be due to in part to the lake basin morphology in this region of Lake Superior as well as the limited period, a few days in late August 1990, when these offshore sites were investigated.

\section{ACKNOWLEDGMENTS}

We thank the captain and crew of the R/V Seward Johnson and pilots and crew of the research submersible Johnson-Sea-Link II from the Harbor Branch Oceanographic Institution. R. Axler, C. Larson, and C. Owen helped with sampling from the R/V Noodin. K. Saxrud helped measure bacterial cells. We are also grateful to D. Anderson for guidance on cell volume formulas. This research was supported by grants from the Legislative Commission on Minnesota Resources and the National Undersea Research Center (NOAA) at the University of Connecticut-Avery Point. Part of this work is also the result of research sponsored by the Minnesota Sea Grant College Program (Project number R/CL21) supported by the NOAA Office of Sea Grant, United States Department of Commerce, under Grant No. US DOC/NA86AA-D-SG112. This paper is journal reprint number JR492. The U.S. Government is authorized to reproduce and distribute reprints for government purposes, not withstanding any copyright notation that may appear hereon.

\section{REFERENCES}

Auer, M.T., and Powell, K.D. 2004. Heterotrophic bacterioplankton dynamics at a site off the southern shore of Lake Superior. J. Great Lakes Res. 30 (Suppl. 1):214-229.

Ammerman, J.W., Fuhrman, J.A., Hagström, Å, and Azam, F. 1984. Bacterioplankton growth in seawater:
I. Growth kinetics and cellular characteristics in seawater cultures. Mar. Ecol. Prog. Ser. 18:31-39.

Azam, F., Fenchel, T., Field, J.G., Gray, J.S., Meyer-Reil, L.A., and Thingstad. F. 1983. The ecological role of water-column microbes in the sea. Mar. Ecol. Prog. Ser. 10:257-263.

Baker, J.E., Eisenreich, S.J., Johnson, T.C., and Halfman, B.M. 1985. Chlorinated hydrocarbon cycling in the benthic nepheloid layer of Lake Superior. Environ. Sci. Technol. 19:854-861.

Bell, R.T. 1990. An explanation for the variability in the conversion factor deriving bacterial cell production from incorporation of $\left[{ }^{3} \mathrm{H}\right]$ thymidine. Limnol. Oceanogr. 35:910-915.

Biddanda, B., Ogdahl, M. and Cotner, J. 2001. Dominance of bacterial metabolism in oligotrophic relative to eutrophic waters. Limnol. Oceanogr. 46:730-739.

Caron, D.A., Goldman, J.C., Anderson, O.K., and Dennett. M.R. 1985. Nutrient cycling in a microflagellate food chain: 2. population dynamics and carbon cycling. Mar. Ecol. Prog. Ser. 24:243-254.

Cho, B.C., and Azam, F. 1988. Heterotrophic bacterioplankton measurement by the tritiated thymidine incorporation method. Ergeb. Limnol. 31:153-162.

Cole, J.J., Findlay, S. and Pace, M.L. 1988. Bacterial production in fresh and saltwater ecosystems: a cross-system overview. Mar. Ecol. Prog. Ser. 43:1-10.

Cotner, J.B., and Biddanda, B.A. 2002. Small players, large role: microbial influence on biogeochemical processes in pelagic aquatic ecosystems. Ecosystems 5:105-121.

Johengen, T.H., and Biddanda, B.A. 2000. Intense winter heterotrophic production stimulated by benthic resuspension. Limnol. Oceanogr. 45:1672-1676.

Coveney, M.F., and Wetzel, R.G. 1992. Effects of nutrients on specific growth rate of bacterioplankton in oligotrophic lake water cultures. Appl. Environ. Microbiol. 58:150-156.

Ducklow, H.W., Purdie, D.A., Williams, P.J. LeB., and Davies. J.M. 1986. Bacterioplankton: a sink for carbon in a coastal marine plankton community. Science 232:865-867.

Fahnenstiel, G.L., Sicko-Goad, L., Scavia, D., and Stoermer, E.F. 1986. Importance of picoplankton in Lake Superior. Can. J. Fish. Aquat. Sci. 43:235-240.

Fallon, R.D., and Boylen, C.W. 1990. Bacterial production in freshwater sediments: cell specific versus system measures. Microb. Ecol. 19:53-62.

Findlay, S.E.G., Meyer, J.L., and Edwards, R.T. 1984. Measuring bacterial production via rate of incorporation of $\left[{ }^{3} \mathrm{H}\right]$ thymidine into DNA. J. Microbiol. Methods 2:57-72.

Fuhrman, J.A., and Azam, F. 1982. Thymidine incorporation as a measure of heterotrophic bacterioplankton production in marine surface waters: evaluation and field results. Mar. Biol. 66:109-120.

Halfman, B.M., and Johnson, T.C. 1989. Surface and ben- 
thic nepheloid layers in the western arm of Lake Superior, 1983. J. Great Lakes Res. 15:15-25.

Hicks, R.E., and Owen, C.J. 1991. Bacterioplankton density and activity in benthic nepheloid layers of Lake Michigan and Lake Superior. Can. J. Fish. Aquat. Sci. 48:923-932.

Hobbie, J.E., Daley, R.J., and Jasper, S. 1977. Use of nuclepore filters for counting bacteria by epifluorescence microscopy. Appl. Environ. Microbiol. 33:1225-1228.

Hwang, S-J., and Heath, R.T. 1997. Bacterial productivity and protistan bacterivory in coastal and offshore communities of Lake Erie. Can. J. Fish. Aquat. Sci. 54:788-799.

, and Heath, R.T. 1999. Zooplankton bacterivory at coastal and offshore sites of Lake Erie. J. Plankton Res. 21:699-719.

Jeffrey, W.H., and Paul, J.H. 1988. Underestimation of DNA synthesis by $\left[{ }^{3} \mathrm{H}\right]$ thymidine incorporation in marine bacteria. Appl. Environ. Microbiol. 54:3165-3168.

Kirchman, D., Ducklow, H., and Mitchell, R. 1982. Estimates of bacterial growth from changes in uptake rates and biomass. Appl. Environ. Microbiol. 44:1296-1307. Suzuki, Y., Garside, C., and Ducklow, H.W. 1991. High turnover rates of dissolved organic carbon during a spring phytoplankton bloom. Nature 352:612-614.

McKee, J.D., Wilson, T.P., Long, D.T., and Owen, R.M. 1989. Geochemical partitioning of $\mathrm{Pb}, \mathrm{Zn}, \mathrm{Cu}, \mathrm{Fe}$, and $\mathrm{Mn}$ across the sediment-water interface in large lakes. J. Great Lakes Res. 15:46-58.

McLain, D.H. 1974. Drawing contours from arbitrary data points. Computer Journal 17:318-324.

Moll, R., and Brahce, M. 1986. Seasonal and spatial distribution of bacteria, chlorophyll, and nutrients in nearshore Lake Michigan. J. Great Lakes Res. 12:52-62.

Moriarty, D.J.W., and Pollard, P.C. 1981. DNA synthesis as a measure of bacterial productivity in seagrass sediments. Mar. Ecol. Prog. Ser. 5:151-156.

Munawar, M., and Munawar, I.F. 2001. An overview of the changing flora and fauna of the North American Great Lakes. Part I: phytoplankton and microbial food web. In The Great Lakes of the World (GLOW): Foodweb, Health and Integrity, eds. M. Munawar and R.E. Hecky, pp. 219-275. Lieden, Netherlands: Backhuys Publishers.

, Munawar, I.F., Culp, L.R., and Dupuis, G. 1978. Relative importance of nanoplankton in Lake Superior phytoplankton biomass and community metabolism. $J$. Great Lakes Res. 4:462-480.

Murray, R.E., and Hodson, R.E. 1985. Annual cycle of bacterial secondary production in five aquatic habitats of the Okefenokee swamp ecosystem. Appl. Environ. Microbiol. 49:650-655.
Pace, M.L. 1988. Bacterial mortality and the fate of bacterial production. Hydrobiologia 159:41-49.

Parkos, W.G., Olson, T.A., and Odlaug, T.O. 1968. Water quality studies on the Great Lakes based on carbon fourteen measurements of primary productivity. Water Resources Research Center Bulletin 17. Minneapolis, MN: University of Minnesota.

Parsons, T.R., Maita, Y., and Lalli, C.M. 1984. A Manual of Chemical and Biological Methods of Seawater Analysis. New York: Pergamon Press.

Pernie, G.L., Scavia, D., Pace, M.L., and Carrick, H.J. 1990. Micrograzer impact and substrate limitation of bacterioplankton in Lake Michigan. Can. J. Fish. Aquat. Sci. 47:1836-1841.

Porter, K.G., and Feig, Y.S. 1980. The use of DAPI for identifying and counting aquatic microflora. Limnol. Oceanogr. 25:943-948.

Psenner, R. 1993. Determination of size and morphology of aquatic bacteria by automated image analysis. In Handbook of Methods in Aquatic Microbial Ecology. eds. P.F. Kemp, B.F. Sherr, E.B. Sherr, and J.J. Cole, pp. 339-345. Boca Raton, FL: Lewis Publishers.

Rao, S.S. 1978. Surface distributions of aerobic heterotrophs and their relationships to temperature and nutrients in Lake Superior during 1973. J. Great Lakes Res. 4:408-414.

Robarts, R.D. 1987. Effect of rainstorms on heterotrophic bacterial activity in a hypertrophic African lake. Hydrobiologia 148:281-286.

Rose, C.L. 1992. Nitrogen and phosphorus limitation of phytoplankton in northeastern Minnesota lakes. M.S. thesis, University of Minnesota-Duluth, Duluth, MN.

Scavia, D., and Laird, G.A. 1987. Bacterioplankton in Lake Michigan: dynamics, controls, and significance to carbon flux. Limnol. Oceanogr. 32:1017-1033.

Sherr, B.F., Sherr, E.B., and McDaniel, J. 1992. Effect of protistan grazing on the frequency of dividing cells in bacterioplankton assemblages. Appl. Environ. Microbiol. 58:2381-2385.

Wainright, S.C. 1990. Sediment-to-water fluxes of particulate material and microbes by resuspension and their contribution to the planktonic food web. Mar. Ecol. Prog. Ser. 62:271-281.

White, P.A., Kalff, J., Rasmussen, J.B., and Gasol, J.M. 1991. The effect of temperature and algal biomass on bacterial production and specific growth rate in freshwater and marine habitats. Microb. Ecol. 21:99-118.

Wilkinson, L. 1989a. SYGRAPH: The System for Graphics. SYSTAT, Inc., Evanston, IL. 1989b. SYSTAT: The System for Statistics. SYSTAT, Inc., Evanston, IL.

Submitted: 9 July 2002

Accepted: 2 October 2003

Editorial handling: Joseph V. DePinto 